\title{
Material Actual Indicator
}

National Cancer Institute

\section{Source}

National Cancer Institute. Material Actual Indicator. NCI Thesaurus. Code C93858.

Specifies whether the material is real (actual) vs. placeholder (kind of). 